\title{
En kvinne i 80-årene med redusert allmenntilstand og hyperkalsemi
}

\author{
Farmakokinetikk og farmakodynamikk viser stor individuell variasjon, \\ kan variere over tid og påvirkes av mange ytre og indre faktorer. Spe- \\ sielt hos pasienter med høy alder, komorbiditet og polyfarmasi kan \\ presumptivt harmløs behandling gi uventede bivirkninger.
}

Øystein Sefland

oystein.sefland@helse-fonna.no

Bjørn Gunnar Nedrebø

Goran Kovacevic

Bjørn Egil Vikse

Medisinsk klinikk

Haugesund sjukehus
En kvinne i 80-årene ble innlagt i medisinsk avdeling grunnet fallerende allmenntilstand og mistanke om pneumoni. Kvinnen var hjemmeboende med godt funksjonsnivå før det aktuelle. Hun hadde kjent hypertensjon og revmatoid artritt. Da pasienten kontaktet lege ti dager før innleggelsen, ble hun diagnostisert med sannsynlig pneumoni, og hun fikk forskrevet en peroral antibiotikakur med ukjent medikament. Under kuren fikk hun bedring av luftveissymptomer, men hun ble økende slapp med følelse av diffust utbredt svakhet i muskulaturen. Hun hadde vansker med å stå oppreist og hun falt flere ganger i hjemmet. De siste dagene var hun kvalm. Hun hadde spist og drukket lite, og avføringen var treg.

Ved undersøkelse var allmenntilstanden nedsatt. Blodtrykket var 176/85 mm Hg, pulsen regelmessig på 62 , temperatur $37,0^{\circ} \mathrm{C}$ og oksygensaturasjonen var $92 \%$ uten tilskudd av oksygen. Hun fremsto adekvat kognitivt og samarbeidet godt. Hudturgoren var nedsatt, og hun hadde tørr munnslimhinne forenlig med dehydrering. Ved klinisk undersøkelse av lunger, hjerte, abdomen og underekstremiteter bemerket man ingenting bortsett fra lette bibasale krepitasjoner ved lungeauskultasjon. Orienterende nevrologisk undersøkelse viste symmetrisk kraftnedsettelse, men normal sensibilitet og reflekser i alle ekstremiteter.

Pasientens medikasjon ved innleggelse var metoprolol depot $100 \mathrm{mg} \times 1$, losartan hydroklortiazid $100 \mathrm{mg} / 12,5 \mathrm{mg} \times 1$, prednisolon $5 \mathrm{mg} \times 1$ og Calcigran Forte $1000 \mathrm{mg} /$ 800 IE $\times 1$. Ca. to uker før innleggelsen hadde revmatolog seponert metotreksat til fordel for prednisolon grunnet luftveissymptomer og mistanke om metotreksatindusert lungesykdom. Ifølge pasienten selv og hennes pårørende pleide hun å ta sine medikamenter som forskrevet.

Klinisk fant man ingen umiddelbar årsak til plagene. Det er ikke uvanlig ved medisinske avdelinger at eldre mennesker i tilsvarende situasjon blir klassifisert som «causa socialis», som hentyder til at det snarere er omsorgsbehov fremfor somatisk sykdom som fører til innleggelse. Man finner likevel ofte somatiske bakenforliggende årsaker som infeksjon, hjerteinfarkt, hjertesvikt, obstipasjon, nyresvikt, anemi eller annen sykdom som lar seg behandle og kan redusere sykeligheten, øke funksjonsnivået og redusere omsorgsbehovet (1).

Røntgen thorax og ultralyd av nyrer og urinveier var normale. EKG viste smalkomplekset sinusrytme 61/min med normal akse, $P Q$-tid, QTc-tid og ingen iskemisuspekte forandringer.

Bruk av angiotensin II-reseptorantagonister eller angiotensinkonvertasehemmere (ACEhemmere) i kombinasjon med dehydrering er en vanlig årsak til akutt nyresvikt. Pasienter som i tillegg står på diuretika er spesielt utsatt.

Blodprøver ved innkomst er vist i tabell 1. Det mest påfallende var pasientens uttalte hyperkalsemi og nyresvikt. Hun ble oppfattet som dehydrert, ultralyd av urinveier var upåfallende, og man mistenkte derfor prerenal nyresvikt. Årsaken til hyperkalsemien kjente man ikke, men på grunn av alvorlighetsgraden ble det $i$ tillegg til intravenøs væskebehandling med natriumkloridoppløsning $9 \mathrm{mg} / \mathrm{ml}$ også gitt infusjon av $90 \mathrm{mg}$ pamidronatdinatrium (et bisfosfonat) og kalsitonin $100 \mathrm{IE} \times 2$. Man overvåket pasienten med telemetri og timediurese. Telemetri viste en enkeltstående episode med åtte sekunders komplett AV-blokk med nodal og ventrikulær erstatningsrytme.

I plasma er omtrent $40 \%$ av kalsium bundet til proteiner og hovedsakelig til albumin. Omtrent $50 \%$ er fritt kalsium (den biologisk aktive fraksjonen), og resten danner komplekser med anioner som bikarbonat, sitrat, sulfat, fosfat og laktat (2). Ved måling av kalsium i serum måles den totale konsentrasjonen av både bundet og fritt kalsium. Når albuminkonsentrasjonen endrer seg, endres total kalsiumkonsentrasjon uten at den biologiske aktive andelen påvirkes signifikant. For bedre å gjenspeile den biologiske aktiviteten 
Tabell 1 Laboratorieundersøkelser ved innkomst

\begin{tabular}{|c|c|c|}
\hline Analyse & Analyseverdi & Referanseverdi \\
\hline B-Hemoglobin (g/dl) & 12,1 & $11,7-15,3$ \\
\hline B-Leukocytter (. 10\%/l) & 14,0 & $3,5-8,8$ \\
\hline $\mathrm{S}-\mathrm{CRP}(\mathrm{mg} / \mathrm{l})$ & 35 & $<5$ \\
\hline S-kreatinin $(\mu \mathrm{mol} / \mathrm{l})$ & 293 & $45-90$ \\
\hline S-karbamid (mmol/l) & 15,1 & $3,1-7,9$ \\
\hline Estimert glomerulær filtrasjonshastighet $\left(\mathrm{ml} / \mathrm{min} / 1,73 \mathrm{~m}^{2}\right)$ & 13 & $>60$ \\
\hline S-natrium (mmol/l) & 133 & $137-145$ \\
\hline S-kalium(mmol/l) & 3,6 & $3,5-5,1$ \\
\hline Total s-kalsium (mmol/l) & 4,68 & $2,15-2,51$ \\
\hline Ionisert s-kalsium (mmol/l) & 2,49 & $1,12-1,32$ \\
\hline S-albumin (g/l) & 31 & $34-45$ \\
\hline Korrigert s-kalsium (mmol/l) & 4,86 & $2,15-2,51$ \\
\hline $\mathrm{B}$-arteriell pH & 7,52 & $7,35-7,45$ \\
\hline $\mathrm{B}$-arteriell $p \mathrm{CO}_{2}(\mathrm{kPa})$ & 5,6 & $4,3-6,0$ \\
\hline $\mathrm{B}$-arteriell $p \mathrm{O}_{2}(\mathrm{kPa})$ & 8,8 & $11,1-14,4$ \\
\hline $\mathrm{B}$-arteriell $\mathrm{HCO}_{3-}(\mathrm{mmol} / \mathrm{l})$ & 34 & $22-26$ \\
\hline B-baseoverskudd (mmol/l) & +11 & $-3-3$ \\
\hline B-klorid (mmol/l) & 88 & $98-107$ \\
\hline B-laktat (mmol/l) & 1,1 & $<1,7$ \\
\hline S-fosfat (mmol/l) & 1,28 & $0,85-1,50$ \\
\hline S-magnesium (mmol/l) & 0,59 & $0,71-0,94$ \\
\hline
\end{tabular}

korrigerer man målt s-totalkalsium for albuminkonsentrasjonen ved hjelp av følgende formel: Korrigert kalsium $=[\mathrm{s}-\mathrm{kalsium}]+$ $0,02 \cdot(40$ - s-albumin (g/l)) (3). Dersom man påviser en forstyrrelse i kalsiumhomøostasen ved hjelp av denne formelen, bør man gå videre med måling av fritt kalsium (ionisert kalsium), som er en mer presis målemetode, spesielt ved nyresvikt. Ved verdier for s-totalkalsium på 2,81-3,19 mmol/1 vurderes pasienten å ha en moderat hyperkalsemi, ved verdier på 3,20-3,50 $\mathrm{mmol} / 1$ alvorlig hyperkalsemi og ved verdier $>3,5 \mathrm{mmol} / \mathrm{l}$ snakker man om hyperkalsemisk krise. Tilsvarende verdier for fritt kalsium er 1,51-1,70 mmol/ 1, 1,71-2,00 mmol/1 og >2,0 mmol/l (4). Dersom pasienten har nevrologiske symptomer med forvirring eller redusert bevissthetsnivå som følge av hyperkalsemi, betegnes tilstanden som hyperkalsemisk krise uavhengig av hvor mye over referanseverdi serumkonsentrasjon er.

Typiske symptomer på alvorlig hyperkalsemi inkluderer somnolens, forvirring, muskelsvakhet, polyuri, polydipsi og redusert tarmmotilitet med påfølgende kvalme, brekninger, obstipasjon og magesmerter (5). Dehydrering som konsekvens av polyuri og kvalme er vanlig. Nevrologiske symptomer er et alvorlig tegn og kan i verste fall progrediere til koma. Det er velkjent at alvorlig hyperkalsemi gir EKG-forandringer med påvirkning av blant annet QT-tid, PQ-tid og ST-T-segmentforandringer, og det er beskrevet maligne takykardier og ledningsblokk som hos vår pasient.

Behandlingen av hyperkalsemi styres av alvorlighetsgrad, hvor raskt tilstanden har utviklet seg og etiologi. Ved lett forhøyede verdier vil behandlingen ofte være rettet mot underliggende tilstand. Ved moderat til alvorlig hyperkalsemi vil det viktigste elementet $\mathrm{i}$ behandlingen være å sørge for økt eliminasjon av kalsium. Kalsiumhomøostasen reguleres via absorpsjon i tarm, ekskresjon i nyrene og bufring med beinvev. Hovedprinsippet $\mathrm{i}$ den akutte behandlingen er å øke diurese gjennom aggressiv væskebehandling med eventuelt tillegg av diuretika. Man kan i tillegg gi bisfosfonater og kalsitonin som hemmer osteoklastaktivitet og reduserer frigjøringen av kalsium fra bein. Effekten av endring i osteoklastaktivitet inntrer i løpet av dager. Kalsitonin hemmer i tillegg renal tubulær reabsorpsjon av kalsium, fosfat og natrium, og denne effekten inntrer raskt (4). Dialyse er også en effektiv metode for å senke s-kalsium, men blir sjeldnere brukt og er mest aktuelt hos pasienter med nedsatt nyrefunksjon og lav urinproduksjon.

For å avdekke årsaken til pasientens alvorlige tilstand ble det dag 2 tatt supplerende utredningsprøver som viste: senkning $64 \mathrm{~mm}(<30 \mathrm{~mm}), \lg \mathrm{G} 7,9 \mathrm{~g} / \mathrm{l}(5,5-16,3 \mathrm{~g} / \mathrm{l})$, $\operatorname{lgA} 3,88 \mathrm{~g} / \mathrm{l} \quad(0,69-5,17 \mathrm{~g} / \mathrm{ll}), \lg M \quad 7,44 \mathrm{~g} / \mathrm{l}$ (0,33-2,93 g/l), s-elektroforese: «Mønster forenlig med aktiv prosess med oligoklonal immunrespons», u-protein <0,14 g/l, parathyreoideahormon (PTH) $<0,7 \mathrm{pmol} / \mathrm{l}$ $(1,6-8,5 \mathrm{pmol} / \mathrm{l}), C A-12540 \mathrm{kU} / \mathrm{l}(<35 \mathrm{kU} / \mathrm{l})$, CEA 1,7 ug/l $(<5 \mathrm{ug} / \mathrm{ll}, \mathrm{s}-25-\mathrm{OH}$-vitamin $D 94$ nmol/l (37-131 nmol/l) og s-1,25(OH), -vitamin D 40pmol/l (39-193 pmol/l).

Utredningsblodprøvene ga ikke noen åpenbar forklaring på pasientens hyperkalsemi. Hyperparathyroidisme var utelukket med lav konsentrasjon av PTH. Intoksikasjon med vitamin $\mathrm{D}$ virket også usannsynlig med normale serumnivåer. Ved siden av hyperparathyroidisme er malign sykdom en av de vanligste årsaker til hyperkalsemi $(6,7)$.

Man supplerte utredningen med CT thorax, ultralyd abdomen, gynekologisk unders $\varnothing$ kelse og benmargsundersøkelse uten å finne holdepunkter for malign sykdom.

Blodprøver tatt ca. ett døgn etter initiale prøver viste bedring av hyperkalsemi med korrigert totalkalsium 4,13 mmol/l. Pasienten hadde adekvat diurese og man kontinuerte væskebehandlingen. I løpet av de åtte dagene pasienten lå inne var det god bedring både klinisk og biokjemisk. Hun opplevdes initialt under innleggelsen som noe forvirret. Dette normaliserte seg helt, og utreisedagen virket hukommelsen normal. Motorisk gikk hun fra ikke å kunne reise seg fra stol til å være oppegående $i$ avdelingen. Laboratorieverdier ved utreise viste korrigert totalkalsium 2,61 mmol/l og kreatinin $226 \mu \mathrm{mol} / \mathrm{l}$. Hun ble utskrevet $i$ habitualtilstand til hjemmet. Angiotensin II-reseptorantagonist, tiazid og kalsium/D-vitamintilskudd var seponert fra innleggelsestidspunktet. Som ny medikasjon hadde hun lav dose slyngediuretikum og kaliumtilskudd.

Tre uker etter utskrivning kom hun til kontroll ved nyremedisinsk poliklinikk, og hun var da $i$ fin form. Laboratorieverdier viste korrigert totalkalsium $2,47 \mathrm{mmol} / \mathrm{log}$ 


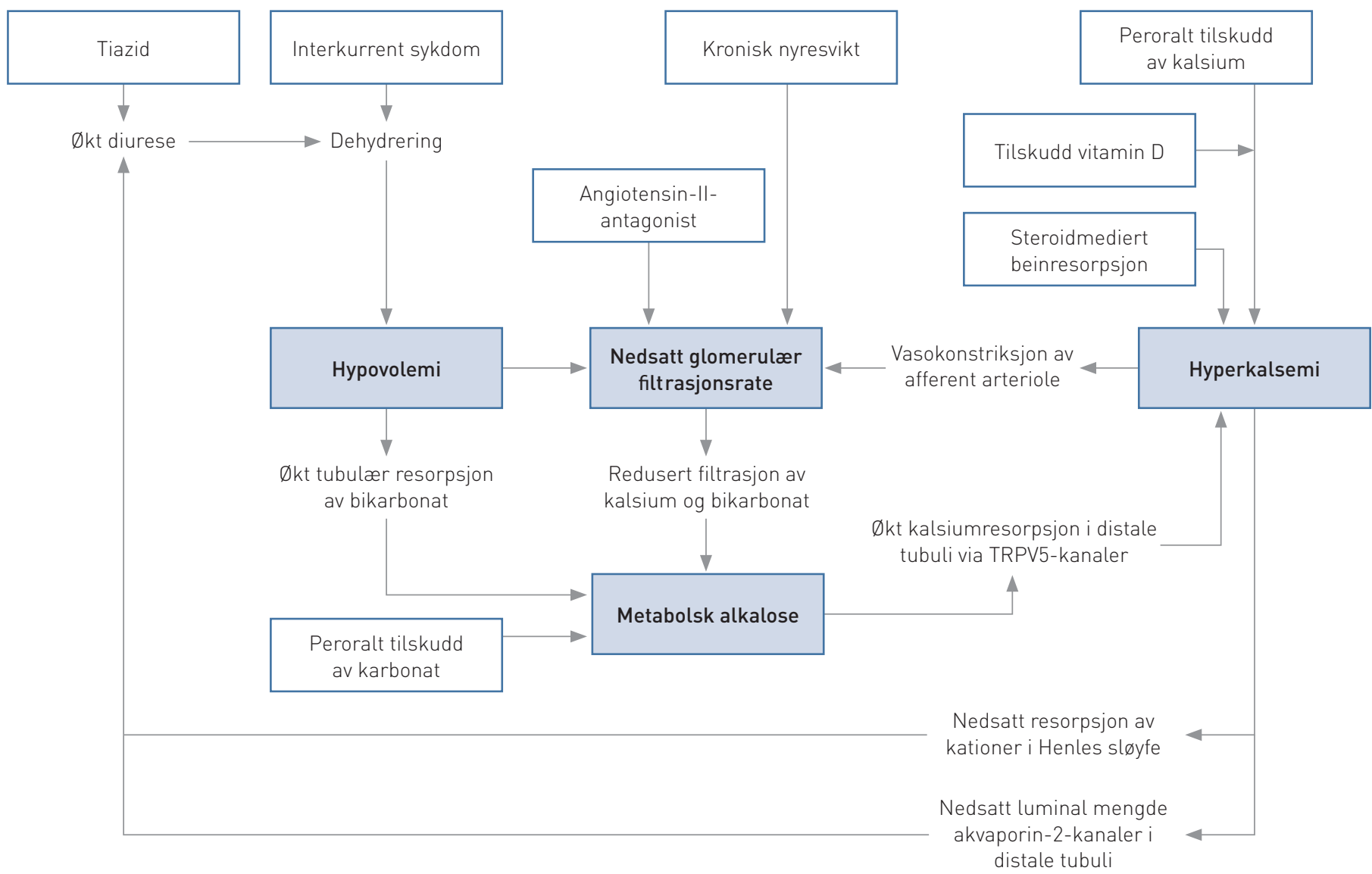

Figur 1 Flere faktorer bidrar sammen til å etablere en selvforsterkende mekanisme, der hovedelementene hypovolemi, nyresvikt, hyperekalsemi og alkalose gjensidig forverrer hverandre. Hyperkalsemi aktiverer som en kompensasjonsmekanisme kalsiumsensitive reseptorer (CaSR) i Henles sløyfe, med nedregulering av kaliumeffluks fra tubuliceller til lumen som følge (13). Dette gir redusert elektrisk spenningsgradient over cellemembranen og redusert influks fra lumen av kalsium, men samtidig også andre kationer. Resorpsjonen av natrium over $\mathrm{Na}-\mathrm{K}$-2Cl-kotransporteren faller og natriuresen stiger. Forhøyet kalsiumkonsentrasjon i den luminale væsken nedregulerer via en annen CaSR-mediert mekanisme mengden akvaporin-2-kanaler luminalt i distale tubuli med påfølgende redusert resorpsjon av fritt vann. Alkalose øker affiniteten for kalsium til CaSR og forsterker ytterligere disse diuretiske mekanismene. I nefronets distale tubuli reabsorberes kalsium transcellulært gjennom kalsiumkanalene TRPV5/6 (transient receptor potential vanilloid receptor). Ved stigende pH oppreguleres aktiviteten til disse kanalene (13)

kreatinin $129 \mu \mathrm{mol} / \mathrm{l}$. Hun ble oppfattet å ha hatt en akutt på kronisk nyresvikt hvor den kroniske komponenten sannsynligvis skyldtes hypertensiv nyreskade. Kontrollblodprøver tatt tre år senere viste stabile forhold med korrigert totalkalsium på 2,29 mmol/l og kreatinin $140 \mu \mathrm{mol} / \mathrm{l}$.

\section{Diskusjon}

Med økende alder reduseres nyrefunksjonen, og den glomerulære filtrasjonsraten (GFR) faller signifikant (5). Eldre mennesker har dessuten økt hyppighet av komorbiditet, polyfarmasi og redusert væskeinntak. Risikoen for å utvikle akutt nyresvikt i forbindelse med interkurrent sykdom er derfor høyere enn hos yngre, og nyresvikt utvikler seg gjerne fortere og med en høyere alvorlighetsgrad. ACE-hemmere, angiotensin IIreseptorantagonister og diuretika er typiske medikamenter som kan utløse en akutt nyresvikt, og det er anbefalt midlertidig seponering av disse ved interkurrent sykdom. Pasienter med risikofaktorer kan overraskende fort utvikle nyresvikt, og klinisk ser vi hyppig alvorlig nyresvikt utløst av kun få dager med sykdom med økt væsketap og/eller redusert væskeinntak.

Hyperkalsemi er en konsekvens av økt kalsiumabsorpsjon i tarm, økt beinresorpsjon og/ eller redusert kalsiumutskilling i nyrer. Hyperparathyroidisme og maligne tumores er de to hyppigste årsakene til hyperkalsemi $(6,7)$. Mindre vanlige årsaker er kronisk granulomatøs sykdom, vitamin D-intoksikasjon, medikamentbivirkninger, immobilisering og melkalkali syndrom. Sistnevnte har i noen studier de siste årene blitt tredje vanligste årsak til hyperkalsemi (6). Hyperparatyreoidisme alene gir sjelden så kraftig hyperkalsemi som hos vår pasient, PTH var lav og det mest nærliggende var å lete etter underliggende malign sykdom (2). Benresorpsjonen ved malignitet skjer enten ved osteolyse i og rundt skjelettmetastaser, eller via systemisk effekt av tumorproduserte stoffer (som oftest parathyreoideahormonrelatert peptid (PTHrP)) som stimulerer osteoklastaktivitet (5). Ved omfattende utredning fant man ikke holdepunkter for malignitet hos denne pasienten. På tross av at vi mangler verdier for PTHrP og ACE kan vi med bakgrunn i pasientens raske, fullstendige og vedvarende remisjon anta at hun ikke hadde kreft eller sarkoidose.

I litteraturen beskrives tilstanden melkalkali-syndrom å være sjelden, men med økende insidens de siste årene etter hvert som kalsiumkarbonat stadig oftere blir brukt som osteoporoseprofylakse (7). I 1915 introduserte legen Bertram Welton Sippy (1866-1924) sin kur mot ulcus pepticum, som blant annet besto av meieriprodukter og alkaliske tilsetninger (8). Kuren ble raskt populær, men viste seg å kunne gi til dels alvorlige bivirkninger som kvalme, oppkast, forvirring, hodepine og nyresvikt. Dette utgjorde melk-alkali-syndromet, men det var først i 1936 at man fant en sammenheng mellom nyresvikt, alkalose og hyperkalsemi (9). I dag stilles diagnosen når følgende er til stede: triaden metabolsk alkalose, hyperkalsemi, nyresvikt og i tillegg anamnese som 
tilsier inntak av kalsium- og basetilskudd. Andre årsaker til hyperkalsemi må ekskluderes.

Calcigran Forte består av kalsiumkarbonat $(1000 \mathrm{mg}$ kalsium $=25 \mathrm{mmol})$ og vita$\min \mathrm{D}_{3}(10)$. Kalsiumkarbonat virker basisk, og løst i vann vil karbonat reagere med hydrogenioner og inngå i en kjemisk likevekt med bikarbonat og karbonsyre (2). Normal dose forventes ikke å gi hyperkalsemi eller alkalose, men man finner i preparatomtalen advarsel om at det skal utvises forsiktighet ved nyresvikt og at pasienter bør monitoreres med tanke på kalsiumnivå i blodet. Ekstra utsatt er eldre mennesker. De har nedsatt regenerasjon av benvev, og evnen til å bufre kalsiumoverskudd er følgelig redusert (11). Gravide som kaster opp er utsatt for hypovolemi og hypokloremisk alkalose og utgjør en annen risikogruppe. Man bør også være observant på samtidig bruk av antacida som f.eks. Titralac, hvor anbefalte døgndoser i henhold til preparatomtalen gir et signifikant tilskudd av kalsiumkarbonat. Eksperimenter på nyrefriske individer har vist at disse kan tåle høye doser av kalsiumkarbonat (7). En del nyresviktpasienter kan også tolerere relativt høye doser uten å utvikle alkalose eller hyperkalsemi, men nyresvikt regnes likevel som en predisponerende tilstand. Det er foreslått at risikofaktorer alene ikke er tilstrekkelig for sykdomsutvikling, men at det i tillegg må foreligge en individuell mottakelighet. Noen mennesker ser ut til å absorbere uforholdsmessig høy fraksjon av kalsium uavhengig av størrelsen på inntaket, og hos en del pasienter med hyperkalsemi finner man at nivået av 1,25-di-OH-vitamin D er inadekvat supprimert (7). Hos vår pasient var nivået av 1,25di-OH-vitamin D helt i nedre referanseområde, og kanskje burde man forventet at dette skulle være enda lavere ved hennes ekstreme hyperkalsemi.

Før innleggelse gjennomgikk pasienten en pneumoni med redusert inntak av væske og økt væsketap ved feber. Dette ga sannsynligvis dehydrering og hypovolemi. Hypovolemi kombinert med samtidig inntak av angiotensin II-reseptorantagonister kan ha gitt fall $i$ GFR, som kan ha medført at filtrasjonen av kalsium og bikarbonat ble redusert. Eliminasjonen av bikarbonat kan ytterligere ha blitt forstyrret ved at det i proksimale tubuli skjedde en økt resorpsjon av natrium og bikarbonat for å motvirke hypovolemi (12). Når hyperkalsemi var etablert, kan dette ha gitt en vasokonstriksjon i afferente arteriole med ytterligere fall i nyregjennomblødning og GFR (7).

Som nærmere beskrevet i figur 1 vil hyperkalsemi og alkalose bidra til å øke diurese $i$ alle av nefronets segmenter (13). Resultatet blir en nefrogen diabetes insipidus. På toppen av dette fikk pasienten diuretisk behandling med tiazid. Trolig tiltok hypovolemien og kompromitterte reguleringen av kalsiumhomøostasen som beskrevet i forrige avsnitt. Oppsummert ser man at ved en etablert tilstand med hovedelementene hyperkalsemi, alkalose og hypovolemi forverres den allerede forutgående reduserte evnen til autoregulering via en selvforsterkende prosess gjennom flere patofysiologiske mekanismer.

Mekanismene ved melk-alkali-syndrom er kompliserte. Behandlingen er derimot enkel. Hypovolemi er et element i patogenesen som er lett tilgjengelig for behandling, og behandlingsprinsippet er volumekspansjon med påfølgende adekvat høy kalsiurese. Med denne behandlingen fikk vår pasient rask normalisering av kalsiumkonsentrasjonen, og etter seponering av antatt utløsende medikamenter har man tre år senere ikke sett residiv.

Kasuistikken beskriver en sjelden, men alvorlig tilstand, og illustrerer hvordan presumptivt ufarlig behandling kan føre med seg uforutsette komplikasjoner. Vi konkluderer med en anbefaling om at pasienter med nevnte risikofaktorer bør følges opp med måling av s-kalsium etter oppstart av tilskudd med kalsium og absorberbare baser.

Pasienten har gitt samtykke til at artikkelen blir publisert.

\section{Øystein Sefland (f. 1980)}

er lege i spesialisering i indremedisin.

Forfatter har fylt ut ICMJE-skjemaet og oppgir ingen interessekonflikter.

\section{Bjørn Gunnar Nedrebø (f. 1952)}

er dr.med., spesialist i indremedisin og i endokrinologi, overlege og førsteamanuensis ved Universitetet i Bergen.

Forfatter har fylt ut ICMJE-skjemaet og oppgir ingen interessekonflikter.

\section{Goran Kovacevic (f. 1957)}

er spesialist i indremedisin og i nyresykdommer og er overlege.

Forfatter har fylt ut ICMJE-skjemaet og oppgir ingen interessekonflikter.

\section{Bjørn Egil Vikse (f. 1977)}

er dr.med., spesialist i nyresykdommer, overlege og professor ved Universitetet i Bergen. Forfatter har fylt ut ICMJE-skjemaet og oppgir ingen interessekonflikter.

\section{Litteratur}

1. Lillebø M-L, Velle HO, Wyller TB. 77 år gamme kvinne innlagt av sosiale årsaker. Tidsskr Nor Legeforen 2012; 132: 426-8.

2. Guyton AC, Hall JE. Textbook of medical physiology. 9. utg. Philadelphia, PA: W.B. Saunders, 1996.

3. National Kidney Foundation. KDOQI Clinical Prac tice Guidelines for Bone Metabolism and Disease in Chronic Kidney Disease. Am J Kidney Dis 2003; 42 (suppl 3): 580

4. Tazmini K. Elektrolyttveileder. 2. utg. Oslo: Diakonhjemmet Sykehus, 2014

5. Feehally J, Floege J, Johnson RJ, red. Comprehensive clinical nephrology. 5. utg. Philadelphia, PA. W. B. Saunders, 2007

6. Picolos MK, Lavis VR, Orlander PR. Milk-alkali syndrome is a major cause of hypercalcaemia among non-end-stage renal disease (non-ESRD) inpatients. Clin Endocrinol (Oxf) 2005: 63: 566-76.

7. Medarov BI. Milk-alkali syndrome. Mayo Clin Proc 2009; 84: $261-7$.

8. Sippy BW. Gastric and duodenal ulcer. JAMA 1915 64: 1625-30

9. Cope $C L$. Base changes in the alkalosis produced by the treatment of gastric ulcer with alkalies. Clin Sci 1936; 2: 287

10. Norsk legemiddelhåndbok. Kap. L23.2.2 Kalsium. http.//legemiddelhandboka.no/Legemidler/ 82266 ? expand $=1$ (6.11.2015)

11. Felsenfeld AJ, Levine BS. Milk alkali syndrome and the dynamics of calcium homeostasis. Clin J Am Soc Nephrol 2006; 1: 641-54

12. Berger BE, Cogan MG Sebastian A. Reduced glomerular filtration and enhanced bicarbonate reabsorption maintain metabolic alkalosis in humans. Kidney Int 1984: 26: 205-8.

13. Patel AM, Goldfarb S. Got calcium? Welcome to the calcium-alkali syndrome. J Am Soc Nephrol 2010; $21: 1440-3$

Mottatt 24.4. 2015, første revisjon innsendt 2.7. 2015, godkjent 6.11. 2015. Redaktør: Liv-Ellen Vangsnes. 